\title{
SENIOR AS ELECTOR AND E-ELECTOR IN COVID 19 PANDEMIC
}

\author{
Agnieszka BÓGDAL-BRZEZIŃSKA * \\ University of Warsaw, Faculty of Political Sciences and International Studies, Krakowskie \\ Przedmieście 26/28, 00-927 Warsaw, Poland, e-mail: bogdal@uw.edu.pl
}

Citation: Bógdał-Brzezińska, A. (2020). Senior as Elector and E-Elector in Covid 19 Pandemic. Revista Română de Geografie Politică, 22(2), 100-106. https://doi.org/10.30892/rrgp.222106-344

\begin{abstract}
The aim of the study is to show the senior as a voter and ICT user in particularly difficult conditions of the threat caused by the Covid 19 pandemic. The studies conducted in twenty seven countries and other studies from August 2020 showed that seniors and men are most exposed to the effects of the disease. This article assumes that e-voting is a safe election solution in a pandemic. Digital divide is a factor that still remains correlated with the age of citizens, even in countries considered technologically advanced. As older voters express more confidence in traditional forms of voting, their attitude slows down the implementation of e-voting in electoral systems. It can be seen that the conservative worldview goes hand in hand with the distrust of seniors in e-voting.
\end{abstract}

Key words: COVID 19, election, e-voting, senior, voting

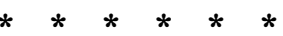

\section{INTRODUCTION}

The global COVID 19 pandemic has affected members of different social groups to varying degrees. Seniors, whose incidence rate was higher than in other generations, felt the most severely. Each country has adopted a specific policy of protecting seniors, and international organizations for health protection, along with the development of subsequent stages of the pandemic, provided guidelines for authorities and citizens on how to best deal with this emergency. Seniors, as a group particularly exposed to the effects of SARS COV2 infection, have become not only the addressees of the health prevention policy, but have also been the subject of quasi-sensational media reports, and finally scientific studies (Daoust, 2020) on the responses of elderly people to the dangers of the pandemic.

The above-mentioned studies conducted in $27^{1}$ countries and other studies from August 2020 showed that seniors and men are most exposed to the effects of the 
disease (Mallapaty, 2020). The analyses showed that although seniors are generally a more disciplined group in relation to other age groups, in the case of life-threatening conditions they adopt much less cautious and responsible attitudes. Isolation, face veil, non-participation in family and social gatherings are not strictly adhered to, which, according to researchers, may result from a temporary or deeply rooted disregard for death, and local and central authorities should take this fact into account in COVID prevention policies. Against the background of insubordination and reckless behaviour of seniors, the example of D. Trump is clearly distinguished, who fell ill on 5 October 2020, and just two days later appeared among voters as a recovering person. This indicates a lack of awareness of the risks associated with later stages of infection, as well as disregard for the health of people for whom it may be a source of infection.

\section{THEORETHICAL REVIEW BASED ON \\ ELECTRONIC VOTING AND ITS RECEPTION}

The subject of electronic voting appeared in the scientific discourse and public debate more than twenty years ago in response to attempts of e-voting introduced in the mid-1990s in countries such as Belgium, India and Brazil. Scientific research referred to the experiences of countries that in the first decade of the $21^{\text {st }}$ century implemented e-voting into their electoral systems despite the awareness of the risk (Musiał-Karg, 2015). It referred to postal voting, adopted and developed at the earliest in a few countries of the world with well-established mechanisms of direct democracy, and at the same time - with a small population inhabiting a relatively large territory (Australia, Canada). The decision criterion allowing postal voting was thoroughly pragmatic, it was about the convenience of the voters themselves, who did not distract themselves from the routine activities in their place of residence. At the same time, through the act of sending the voice, they expressed their support for the democratic system as well as trust in the state and its missionary institutions (post office). Thus, the procedure perpetuated the feeling of servitude of the state towards society (political liberalism), weakening the conviction about the practices of manipulating the urn (Wendt and Bógdał-Brzezińska 2020). Electronic voting is the next stage of broadening the spectrum of interpretation of what conditions can guarantee the attribute of direct elections. As there are various forms of evoting, one can distinguish voting in polling stations with the use of voting devices connected to the national computing system (allowing for faster counting of results) or without such a connection, but only for digital recording of votes, as well as voting outside polling stations for using devices connected to digital networks admitted for use in the election procedure (Mider, 2011).

The attitude to e-voting (and its variant - i-voting) is as much a function of voters' age correlated with their digital competences, as well as the level of social trust in the presence of digital technologies in election procedures (Yao et al., 2006). There are also competence dilemmas, because while the requirement of correspondence voting was the ability to read and write, in electronic voting, digital illiteracy is a dilemma, which is often faced by the elderly and people living in poverty. Based on research conducted a decade ago in culturally diverse

\footnotetext{
${ }^{1}$ The following countries are included in the study: Australia, Brazil, Canada, Denmark, Finland, France, Germany, Hong Kong, Italy, Japan, Malaysia, South Korea, Mexico, the Netherlands, Norway, Philippines, Saudi Arabia, Singapore, South Korea, Spain, Sweden, Taiwan, Thailand, United Arab Emirates (UAE), United Kingdom, United States (US) and Vietnam.
} 
countries (Taiwan, Switzerland, Colombia, Argentina), it was concluded that procedures similar to traditional voting (electronic election kiosks) are more trusted than voting using the Internet (Milic et al., 2016; Alvarez et al., 2011). The subjective perception of the safety of election procedures depended on the ease of use of digital tools by voters, the perceived usefulness of their use in elections, and an open attitude to technological innovation (Chiang, 2009; Barthel et al., 2020). On the other hand, in recent years, the relationship between the systems of states using e-voting (especially unstable democracies) and the level of trust in election procedures as a synonym for trust in power has been noticed (Avgerou et al., 2019).

Moreover, in countries that do not use e-voting tools (e.g. in Poland), as a result of generational changes, opinions of young politicians and voters are heard more and more often about the traditional procedure of voting as a manifestation of extreme conservatism of society. The term "electoral gerontocracy" is used as a pejorative example of slowing down the digitization of electoral procedures by senior voters. This is part of the global discourse on the challenges to democracy posed by the digitization of public life (Kneuer, 2016), but at the same time it deepens the psychological aspects of digital exclusion. It is assumed that traditional methods of voting in elections guarantee the participation of an older electorate and eliminate the willingness to participate on the part of young, digitized but impatient voters for whom visiting a polling station is an irritating burden (Goerres, 2007).

\section{RESEARCH ASSUMPTIONS}

This article assumes that e-voting is a safe election solution in a pandemic. They are supported by intergovernmental organizations and integration structures In the official materials of the EU and the Council of Europe, as well as the WHO, the topic of dilemmas concerning the rule of law and maintaining electoral standards in a pandemic has been addressed in recent months. The Council of Europe indicates as a basis for safe and lawful voting Recommendation CM / Rec (2017) 5 of the Committee of Ministers to member States on standards for e-voting (Recommendation CM, 2017). The dominant belief is that the key conditions that must be met are gradual testing of the electronic procedure, guarantees of the security of the election procedure, even in the event of cyber-attacks, the reliability of the electronic system at every stage of the procedure, the universal availability of digital tools used in the election procedure and, finally, the state's full responsibility for the conduct of the election process e-elections. There is also a clear message that it is the duty of the authorities to skilfully balance between protecting citizens' health and guaranteeing the rule of law (Voting COVID 19). So although international institutions call for state authorities to ensure optimal voting conditions, it is not always understood, especially in the case of countries whose regimes are clearly authoritarian.

However, older voters, whose security could be enhanced through the use of digital tools, are reluctant to replace traditional voting with e-voting. It is influenced by various factors, including the level of digital competences, the level of trust in ICT, and finally the specificity of decision-making by seniors (including election decisions). Therefore, a thesis will be put forward that in countries that do not have legal regulations allowing e-voting, the older electorate approves and maintains the existing state of affairs with its attitudes. 


\section{AGE FACTOR AS A DETERMINATION OF ELECTORAL DECISIONS SENIORS FOR MODERN TECHNOLOGIES}

The age factor turns out to be an important vector of the attitude towards elections in their traditional and remote form. In many countries without legal regulations on electronic voting, a discussion has developed in recent years on the legitimacy of the digitization of elections, the background of which were generational changes among voters. For example, in Poland, as early as 2010, there was a discussion on lowering the age of potential voters to the age of 16 . Experts dealing with scientific political processes took part in the debate. In an interview for the „Polityka” (weekly magazine), K. Skarżyńska, professor of political psychology, emphasized that the age factor plays one of the most important roles in the processes of political decision-making, and the mechanisms governing the decisions of young people radically differ from the decisions of seniors (Skarżyńska, 2010). She pointed out that both groups considered the environment that the researcher had tentatively divided into family and peers as a significant variable. While young people trying to emancipate from the family environment seek to get closer to their peers, which results in potential decisions imitating the choices of peers, seniors show a farreaching readiness to make autonomous decisions in relation to the family and peer environment. In the latter case, life experience plays a significant role, which will be discussed later, which, in connection with education, constitutes a strong foundation for separate views and individualized identity. Simply put, it is easier for seniors to consciously keep separate views and defend them.

At the same time, studies on the impairment of perception and cognition under the influence of aging confirm the decline in the ability to remember and associate. It is alleged that this indirectly influences "information processing and decision-making strategies by older citizens. In a study on political candidate evaluation processes in elections, "older people used less information, but it took more time to check and make a choice" (Riggle and Johnson, 1996). This was in line with previous research, indicating a specific generational methodology of acquiring knowledge by seniors. They showed that older people spend more time searching for information and making decisions, look for less available information, are more systematic or strategic in their searches, which results from their experience, and they are less excited about news and less often change their worldview (including political preferences), and the selection of the sought information serves to increase knowledge organized in a specific way. The latter feature corresponds to the above-mentioned relatively high decisionmaking autonomy. In the case of online voting, comparisons of the attractiveness of this method for young adults (18-25) and seniors (over 60) in US resulted in a clear differentiation of opinions (Powell et al., 2012).

For comparison - in the research on the methodology of election decisions of seniors in the USA twenty years ago, differences resulting from the adaptation potential and the state of consciousness of this group were noticed (Binstock, 2000). Above all, however, there was a high voter turnout of seniors, which made them a reliable electorate, the number of voters over 65 years increased by $5 \%$ between the mid-1960s and the mid-1990s, which results both from the higher percentage of seniors in the national population and declining participation in elections by younger generations. In 2016, the number of active voters in the US over 65 years was $27 \%$, and the percentage of members of electoral commissions in the same age group was $58 \%$. It should be concluded that in democratic 
countries seniors are the iron electorate, willingly and confidently participating in the election procedure.

If we follow the electoral activity of seniors in countries such as Poland, where e-voting does not exist, it will be easy to notice the relationship between the declared level of digital competences and the distrust of digitization of elections and right-wing voting preferences (Ścigaj, 2019). According to a study by the Central Statistical Office in Poland entitled "The use of information and communication technologies in households in $2019 " 53,2 \%$ of people aged $65+$ have never used the Internet, and $82 \%$ of this group did not feel such a need. In studies conducted in Poland around the generational division of digital competences for the 65+ age group, results were obtained showing the lack of interest in ICT.

Table 1. Digital competences of polish seniors

Source: own calculation based on: Wykorzystanie technologii informacyjno-komunikacyjnych w gospodarstwach domowych w 2019 roku - część 3, 2020, GUS: Warszawa

\begin{tabular}{|c|c|}
\hline Digital competences & Age \\
\hline Not using the internet & $\mathbf{5 3 , 2} \%$ \\
\hline Lack competences & $\mathbf{1 1 , 7 \%}$ \\
\hline Low competences & $\mathbf{2 6 , 2} \%$ \\
\hline Basic competences & $\mathbf{6 , 9} \%$ \\
\hline Above average competences & $\mathbf{2 , 0} \%$ \\
\hline
\end{tabular}

The traditional way of obtaining information does not go hand in hand with being open to digital technologies and the Internet. Polish seniors obtain their knowledge first of all from public media, which is the most accessible channel of information, and for people over 75 - completely free. Public media, under the control of the ruling right wing, emit a message saturated with patriotic and religious content, consistent with the world view of the majority of older viewers and listeners. The relationship between age and the dominant world view translates into the voting preferences of this group. This is also shown by the results of the parliamentary elections in Poland in 2019, when: in the group of people aged 50-59, the conservative coalition called the United Right obtained $51 \%$ of the votes; centrist Civic Coalition - 26.3\%; Polish People's Party, traditionally associated with the rural electorate - 9.9\%; the postcommunist Sojusz Lewicy Demokratycznej - 9.2\%, and the nationalist-liberal Confederation - 2.8\%. The United Right gained the greatest support among people aged over 60 , where $55.6 \%$ of voters voted for this party, the Civic Coalition received $25.3 \%$ of support in this group, the Democratic Left Alliance $10 \%$, the Polish People's Party - $7.4 \%$, while the Confederation $-1.1 \%$. In total, among retirees and disability pensioners, the right-wing groups obtained $56.8 \%$ of the vote against $24.5 \%$ for the Civic Coalition, $10.3 \%$ for the Democratic Left Alliance, $6.8 \%$ for the Polish People's Party and only $1.1 \%$ for the Confederation. 
Similarly, on June 28, 2020, the presidential election in Poland was won by Andrzej Duda, associated with the right-wing option, reaching $58 \%$ of the votes among voters over 60 years, whose turnout was estimated at $56.1 \%$.

Andrzej Duda is now 48 years old, he is a relatively young president. It can be noticed, however, that conservative older Polish voters willingly vote for their peers. When the law lowering the retirement age was introduced in 2017, 38 MPs and 33 MPs (mostly from the right) were included in the group covered by the new regulations. At the end of the term of office in 2019,51 out of 131 members of parliament and 69 out of 329 members were of retirement age. The age profile of members of the Polish parliament is not conducive to initiating a legislative debate on the introduction of e-voting and results in the lack of effective solutions in a crisis situation such as the COVID 19 pandemic.

\section{CONCLUSION}

Digital divide is a factor that still remains correlated with the age of citizens, even in countries considered technologically advanced. As older voters express more confidence in traditional forms of voting, their attitude slows down the implementation of e-voting in electoral systems. It can be seen that the conservative worldview goes hand in hand with the distrust of seniors in evoting. This distrust is structural and long-term, so in an intense but sudden threat of COVID 19, it does not affect readiness to replace direct voting at polling stations with electronic voting.

\section{REFERENCES}

Alvarez, R.M., Katz, G., \& Pomares, J. (2011). The impact of new technologies on voter confidence in Latin America: Evidence from e-voting experiments in Argentina and Colombia. Journal of Information Technology \& Politics, 8(2), 199-217.

Avgerou, C., Masiero, S., \& Poulymenakou, A. (2019). Trusting e-voting amid experiences of electoral malpractice: The case of Indian elections. Journal of Information Technology, 34(3), 263-289.

Barthel, M., \& Stocking, G. (2020). 'Older People Account for Large Shares of Poll Workers and Voters in US General Elections. Pew Research Center, FactTank, April, 6. [URLhttps://www.pewresearch.org/fact-tank/2020/04/06/older-people-account-for-large-sharesof-poll-workers-and-voters-in-u-s-general-elections/], (access 07.10.2020).

Binstock, R.H. (2000). Older people and voting participation: past and future. The Gerontologist, 40(1), 18-31.

Chiang, L. (2009). Trust and security in the e-voting system. Electronic Government, an International Journal, 6(4), 343-360.

Daoust, J.F. (2020). Elderly people and responses to COVID-19 in 27 Countries. PloS one, 15(7), e0235590.

Goerres, A. (2007). Why are older people more likely to vote? The impact of ageing on electoral turnout in Europe. The British Journal of Politics and International Relations, 9(1), 90-121.

Kneuer, M. (2016). Measuring the Quality of Democracy. International Political Science Review /Revue internationale de science politique, 37(5), 666-678.

Mallapaty, S. (2020). The coronavirus is most deadly if you are older and male-new data reveal the risks. Nature, 16-17.

Mider, D. (2011). Głosowanie przez Internet a demokracja. Studia politologiczne, 20, 222-267.

Milic, T., McArdle, M., Serdült, U. (2016). Attitudes of Swiss Citizens Towards the Generalisation of E-Voting, Studienberichte des Zentrums für Demokratie Aarau, 10, 1-30.

Musiał-Karg, M. (2015). Głosowanie elektroniczne jako alternatywna metoda uczestniczenia w wyborach-opinie Polaków. Political Preferences, (10), 87-107.

Powell, A., Williams, C.K., Bock, D.B., Doellman, T., \& Allen, J. (2012). e-Voting intent: A comparison of young and elderly voters. Government Information Quarterly, 29(3), 361-372.

Recommendation CM/Rec (2017). 5 of the Committee of Ministers to member States on standards for e-voting, https://search.coe.int/cm/Pages/result_details.aspx?ObjectId=0900001680726f6f]. 
Riggle, E.D., \& Johnson, M.M. (1996). Age difference in political decision making: Strategies for evaluating political candidates. Political Behavior, 18(1), 99-118.

Ścigaj, A. (2019). E-voting czyli demokracja online: Kukiz'15. 28.08.2019, [URL - https://www. youtube.com/watch?v=k0GTa9BD2i4] (access 27.09.2020).

Skarżyńska K., Czy wiek ma wpływ na poglady polityczne? „Polityka” 23.02.2010, /URL - https:// www.polityka.pl/tygodnikpolityka/spoleczenstwo/1503718,1,czy-wiek-ma-wplyw-na-pogladypolityczne.readl, (access 30.09.2020).

Voting and COVID 19, (2020) [URL - https://rm.coe.int/election-and-covid-19/16809e20fe (access 27.09.2020).

Wendt, J.A., Bógdał-Brzezińska, A. (2020). Presidential Elections in Poland and the United States and Democracy. Revista Română de Geografie Politică, 22(2), 61-70.

Wykorzystanie technologii informacyjno-komunikacyjnych w gospodarstwach domowych w 2019 roku - część 3; https://stat.gov.pl/obszary-tematyczne/nauka-i-technika-spoleczenstwoinformacyjne/spoleczenstwo-informacyjne/wykorzystanie-technologii-informacyjnokomunikacyjnych-w-jednostkach-administracji-publicznej-przedsiebiorstwach-igospodarstwach-domowych-w-2019-roku,3,18.html (access 29.09.2020)

Yao, Y., Okoli, C., Houston, A., \& Watson, E. (2006). Demographic differences in attitudes toward remote electronic voting systems. Journal of Computer Information Systems, 47(2), 34-45.

Submitted:

Octomber 02, 2020
Revised:

November 04, 2020
Accepted and published online: November 13, 2020 